\title{
DEVELOPMENT OF PERINATAL MEDICINE IN UKRAINE IN THE CONTEXT OF INTERNATIONAL APPROACHES
}

DOI: 10.36740/WLek202103237

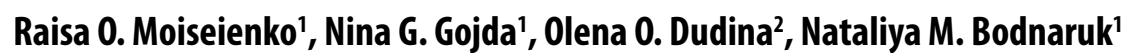 \\ 'P.L.SHUPYK NATIONAL MEDICAL ACADEMY OF POST-GRADUATE EDUCATION, KYIV, UKRAINE \\ 2STATE INSTITUTION INSTITUTE OF PEDIATRICS, OBSTETRICS AND GYNECOLOGY NAMED ACADEMIC ELENA M.LUKIANOVA, \\ NATIONAL ACADEMY OF MEDICAL SCIENCES OF UKRAINE, KYIV, UKRAINE
}

\begin{abstract}
The aim: To realize analysis and assessment of completeness and efficacy in the field of perinatal aid regionalization in Ukraine.

Materials and methods: A retrospective analysis has been carried out as well as assessment of inculcation steps concerning regionalization of perinatal health care in Ukraine according to the data of state and branch statistics and monitoring (in 2013-2017). The methods used here are systemic approach, bibliography method, and statistical data evaluation.

Conclusions: It is shown the modern globally acknowledged three-level system of perinatal health care has been organized and functions in Ukraine, perinatal tertiary level centers are now act in the majority of regions. The perinatal health care realization during these last years is shown to be able to assure the providing of adequate perinatal aid taking into consideration the calculated data concerning the pregnant women concentration with high perinatal risks in third level institutions; these patients include pregnant women with heart defects (63.2-69.9\%), circulatory system defects (48.5-50.5\%), diabetes mellitus (46.7-53.3\%); in institutions of the second-third levels, there are 74.2$83.0 \%$ of patients with severe gestoses. According to functional possibilities of perinatal aid institutions of different levels, they assure $62 \%-64.5 \%$ of births with body mass $500-999 \mathrm{~g}$ and $53.9 \%-55.3 \%$ of ones with body mass $1000-1499 \mathrm{~g}$ in perinatal clinics of the third level; it guarantees the survival of newborn babies with body mass $500-999$ $\mathrm{g}$ and $1000-1499 \mathrm{~g}$ during their first $168 \mathrm{~h}$ reaching $60.1-65.1 \%$ and $89.4 \%-90.4 \%$, respectively.

Efficacy of perinatal aid regionalization is confirmed by a positive tendency of perinatal mortality index; it has become significantly lower: in 2010, the perinatal mortality reached 10.54 cases per 1,000 of newborn alive and dead babies, this index having dropped to 8.89 in 2019 . The maternal mortality levels have also decreased from 23.5 up to 14.9 cases per 100,000 of babies born alive.

Perinatal aid regionalization in Ukraine is being realized according to international strategies permitting to provide effective perinatal aid to patients at each level of its provision depending on patient's need.
\end{abstract}

KEY WORDS: Perinatal health care, regionalization, pregnant women morbidity, newborns morbidity

Wiad Lek. 2021;74(3 p.II):761-766

\section{INTRODUCTION}

The world community at any stage of mankind development determines some priorities to assure the population health protection as the leading resource necessary for life maintenance on the Earth. Such directions of medicine development are usually elaborated by different international institutions. Among the most important global health problems, the leading one is the problem of mother and child health protection including the protection of women reproductive health. It is clear from a series of international documents including the following:

- Convention on the Human Rights [1];

- Convention on the Rights of the Children [2];

- Program of Actions of the International Conference on the Problems of Population and Development (Cairo) [3];

- Action Platform Accepted by the IV Global Conference about the State of Women [4];
- Health-21: Fundamentals of Health Policy for all in the WHO European Region: Introduction (European Series for Health of all) [5];

- UNO Millennium Declaration - Millennium Development Goals for 2000-2015 [6];

- Resolution of the General Assembly of the UNO "Goals of Permanent Development. 2016-2030" [7];

- Global Strategy for Women's, Children's and Adolescents' Health (2016-2030). Every Woman, Every Child [8].

These documents, especially three last ones, include target indices of mother and children health which are to be achieved by all countries during a clearly determined period.

For example, the list of development goals during the next years of this millennium (2000) declares:

- to decrease the babies mortality by two thirds;

- to decrease the mothers mortality by three quarters; 
- to assure the common access to reproductive medicine. The achievement of such Goals has globally built the health of women and children, including, without any doubt, the situation in Ukraine [9].

The results of these documents realization were summed up, and next new tasks for the next period of human history were proposed for the UNO order of the day [7]. In 2015, new Goals of Persistent Development were formulated, well grounded, and confirmed by representatives of 193 countries.

There are 17 such Goals. The third one is "the support of better health". It is formulated as an integral requirement containing, however, a series of detailed tasks. They include, in particular, the necessity to decrease:

- maternal mortality on the global scale below 70 cases per 100,000 of alive born babies;

- neonatal mortality at least to 12 cases per 1,000 of alive born babies in each country;

mortality of children below five years at least to 25 cases per 1,000 of alive born babies in each country.

More detailed steps regarding the protection of women and children health are contained in the European plan of actions for the protection of sexual and reproductive health during 2017-2020 based on the Declaration of Human Rights.

The leading principles of this Plan include:

- each person's right for the highest health level;

- acknowledgement of the fact the health to be the state of complete physical, psychical, and social well-being, not only the absence of diseases and physical defects;

- concordance with general understanding of situation, politics, and priorities of the strategy given in the "Health-2020";

- conformity with international goals and tasks, in particular with actual goals of the Order of day in the field of permanent development up to 2030 and Global Strategy for Women's, Children's and Adolescents' Health (2016-2030) [8];

- succession in health care services providing, principle requiring the health care to be spread on all the human life periods (life stages).

Three goals are presented in the European Plan of Actions (A, B, C). The goal B consists in approaches promoting the reproductive health and well-being protection, including also reproductive rights realization. It foresees the shortening of unsatisfied need scale in contraception, decreases of maternal mortality and morbidity levels for avoidable cases including the causes of dangerous abortions, decrease of perinatal mortality and morbidity levels for avoidable cases, promoting of infertility prophylaxis, providing of infertility diagnostics and treatment.

\section{THE AIM}

Aim of the study was to to realize analysis and assessment of completeness and efficacy in the field of perinatal aid regionalization in Ukraine.

\section{MATERIALS AND METHODS}

A retrospective analysis has been carried out as well as assessment of inculcation steps concerning regionalization of perinatal health care in Ukraine according to the data of state and branch statistics and monitoring (in 2013-2017). The methods used here are systemic approach, bibliography method, and statistical data evaluation.

\section{REVIEW}

In the course of perinatal aid regionalization (PAR) supported by international organizations, a system has been worked out and implemented including the management algorithm for women and newborn babies with perinatal risks as well as the teaching strategy for medical staff for perinatal centers to assure the perinatal care and management of newborn babies with extremely low body weight at the moment of birth [10].

We have proved the efficacy and success of perinatal aid regionalization in some regions of Ukraine have been achieved due to:

- formation in each region of an organizational structure by attributing of obstetrics clinics to certain levels of perinatal aid;

- setting up of organizational structure to correspondence with territorial necessities, taking into account geographical accessibility, geographical necessity, staff and logistic resources of perinatal aid institutions, quantity of pregnant women with different degrees of perinatal pathology risks and mortality;

- working out of schemas (itineraries) for territorial transport intended for pregnant women, parturient women, and newborn babies with high risk of maternal and perinatal mortality in institutions of perinatal aid of adequate level. From the date of the Program confirmation, a three-level perinatal aid system has been organized in all the Ukraine regions, third-level PCs having appeared in the majority of them, excluding Vinnytsia, Zakarpattia, Kyiv, Mykolayiv, Odessa, Kherson, Cherkasy, Chernivtsi, and Chernigiv regions. Unfortunately, three of them are situated on territories being not controlled by Ukrainian administration (such towns as Donetsk, Lugansk, and Simpheropol).

Full of value functioning of perinatal centers permits to affirm the achievement of goals having been mentioned at the moment of creation of the conception concerning the perinatal aid regionalization in our country.

One of such goals was the concentration of pregnant women with severe extra-genital pathologies preventing child-bearing in perinatal centers of the third level. Our analysis shows in 2014-2017 the index of delivery concentration for such women with impaired cardiac functions in third-level perinatal aid institutions comparing to their total quantity in Ukraine to reach $63.2-69.9 \%$, this index in Zhytomyr, Zaporizhzhia, Kirovograd, Kharkiv, Poltava, and Rivne districts being 92.2, 90.29, 85.0, 98.9, 100, and $100 \%$, respectively.

As concerns cases of pregnant women with circulatory problems, the situation is the following. Generally saying, 
almost a half of such patients (48.5-50.5\%) are often concentrated and managed at third level institutions. At the same time, it is possible to concentrate in such institutions significantly more women with pathologies mentioned above. Consequently, this index in some regions is evidently higher reaching 80.7, 88.9, and 84.9\% in Kirovograd, Poltava, and Kharkiv districts, respectively [11].

As concerns pregnant patients with diabetes mellitus, 46.7-53.3\% of them are taken to third level perinatal aid institutions. Both the correct selection and rational medical itineraries for pregnant patients with such pathology permit to increase this index in Kharkiv, Zhytomyr, and Poltava districts up to $99.3,100$, and $100 \%$, respectively.

Correct medical itineraries for pregnant patients with severe gestoses are provided in Kirovograd, Poltava, Kharkiv, and Khmelnytski districts, more than a half of their patients with such pathology being taken to third-level PCs with all the possibilities to provide all the necessary health care services according to standards based on the medicine of evidence.

During the period of perinatal aid regionalization in Ukraine, alive babies are mostly born in third-level obstetrics centers, including $62-64.5 \%$ of babies with the body mass $500-999 \mathrm{~g}$ at the moment of birth and $53.9-55.3 \%$ of ones with this index reaching 1000-1499 g.

In regions possessing third-level PCs the situation is significantly better. For example, the percent of babies with extremely low body mass at the moment of birth (500-999 g) who have been born in such centers reaches $90 \%$ in Zhytomyr region, the concentration indices for such babies in Kharkiv region, Kyiv-City, and Poltava region being 92.1, 70.2 , and $100 \%$, respectively.

The index of delivery concentration for newborn babies with the body mass of 1000-1499 $\mathrm{g}$ at the moment of birth reaches in third-level PCs in Ukraine as a whole 53.9\%$55.3 \%$, these indices in Zaporizhzhia, Poltava, and Kharkiv districts being $80.4 \%, 89.7 \%$, and $88.4 \%$, respectively.

Consequently, we may assess more positive features due to accessibility of highly specialized perinatal aid in regions where third-level PCs have been organized.

Index of neonatal transfers is an additional index of perinatal aid regionalization accepted also in other European countries. It describes the quantity (portion, percent) of newborn babies having been transported to other perinatal aid institutions. The known current index of emergent newborn transfer in countries of European Community reaches $0.5-1.0$ per 100 babies born alive.

Year in year out, the index of neonatal transfers becomes lower, especially in regions where third level perinatal centers are organized and function. In such regions as Dnipropetrovsk, Kirovograd, Poltava, Kharkiv and in Kyiv-City this index varies from 0.7 up to $3.9 \%$.

The goal of perinatal aid regionalization is to increase the quality and availability of perinatal aid taking into account the rational use of existing system providing health care services to women of reproductive age, pregnant women, parturient ones as well as to newborn babies; it is necessary to assure all the possibilities for management of babies with low and extremely low body mass at the moment of birth.
Nowadays, the decrease of perinatal and baby mortality in developed countries is due, first all, to increased quality of health care for children with extremely low body mass.

According to the data obtained from monitoring and assessment of perinatal aid regionalization in Ukraine as a whole, for newborn babies with extremely low body mass at the moment of the birth, the survival frequency dynamics during their first $168 \mathrm{~h}$ of life in 2014-2017 was wave-like; in cases of the body mass $500-999 \mathrm{~g}$, the survival frequencies were $65.1,63.9,64.9$, and $60.1 \%$ in 2014,2015 , 2016, and 2017, respectively. For newborn babies with the body mass $1.000-1.499 \mathrm{~g}$ the frequencies for the same years were $89.4,90.4,90.2$, and $88.5 \%$, respectively. These data become closer to indices known for the USA, Japan, and the majority of Western Europe countries [12].

According to monitoring data obtained during these last 4 years, some rather high survival indices for newborn babies with extremely low body mass at the moment of birth are registered in Dnipropetrovsk and Mykolayiv regions and in Kyiv-City; such indices are lower (below 60\%) in Ivano-Frankivsk, Kirovograd, Sumy, Khmelnytski regions.

Significantly lesser geographical differences are found for survival indices of newborn babies whose body mass at the moment of birth reaches 1000.0-1499.0 g: the data obtained are 83.8-96.8, 86.2-95.9, 80.5-100, and 81.0-100\% in 2014, 2015, 2016, and 2017, respectively [12].

Efficacy of perinatal aid regionalization is confirmed by a positive tendency of perinatal mortality index; it has become significantly lower: in 2010 the perinatal mortality reached 10.54 cases per 1,000 newborn alive and dead babies, this index having dropped to 8.89 in 2019 . The maternal mortality data have also decreased from 23.5 up to 14.9 cases per 100,000 of babies born alive.

\section{DISCUSSION}

Both the realization of strategic goals of international documents and the data of analysis concerning the health level of mothers and children in Ukraine have become a basis for elaboration and realization of some organizational measures to improve the existing situation.

As a fact, the level of morbidity and disease prevalence among adolescent girls being future mothers is for the present rather high and becomes worse from year to year. In 2000, morbidity and prevalence were $8,370.1$ and $14,446.3$ per 10,000 of adolescent girls; in 2017, however, these indices have reached $12,440.7$ and 22,103.9, respectively $[11,13]$. It is quite predictable the prevalence of some extra-genital diseases and syndromes in pregnant women remains as high as before. Defects of circulation and of urogenital systems are registered in 6.6-7.6\% and in $13.1-13.9 \%$ of pregnant patients, respectively. In addition, about $30 \%$ of pregnant women are victims of anemia [11]. It is clear that about a half of pregnant women suffer from different extra-genital pathologies being a negative influence factor for pregnancy and delivery course as well as for intra-uterine fetus development and also for newborn, carrying a high risk for mother's and child's life and health. 
Table I. Comparative data of perinatal reproductive losses among full term and premature newborn babies in Ukraine 2016

\begin{tabular}{ccccc}
\hline Index & $\begin{array}{c}\text { Full term + } \\
\text { premature newborns }\end{array}$ & $\begin{array}{c}\text { Full term } \\
\text { newborns }\end{array}$ & $\begin{array}{c}\text { Premature } \\
\text { newborns }\end{array}$ & $\begin{array}{c}\text { Difference of } \\
\text { indices (by times) }\end{array}$ \\
\hline Perinatal mortality (per 1,000 newborn alive + still babies) & 8.66 & 4.80 & 135.23 & 28.2 \\
\hline Early neonatal mortality (per 1,000 alive newborn babies) & 3.05 & 1.50 & 63.11 & 42.1 \\
\hline Still births (per 1,000 newborn alive and still babies) & 5.68 & 2.67 & 76.98 & 28.8 \\
\hline Morbidity of newborn babies (per 1,000 alive born babies) & 157.7 & 123.8 & 792.0 & 6.4 \\
\hline
\end{tabular}

Without any doubt, this conclusion is confirmed by the analysis of causes of perinatal, neonatal, and baby mortality as well as of still births. For example, more than a half of mortality cases (53.1\%) in the mortality structure of children during the first year of their life are due to conditions having been developed during the prenatal period. In the still births structure, about $75.5 \%$ of all cases are results of intra-uterine hypoxia and asphyxia. The same is the cause of about $58.5 \%$ baby deaths in their early neonatal period [14].

An important problem for Ukrainian health care during many years is non-carrying of pregnancy, especially as a result of preterm delivery, its level in Ukraine varying in limits of 4-5\%. At the same time, the health level of preterm newborn babies and their survival index are a permanent cause of our anxiety. We have carried out a comparative study of perinatal reproductive losses among full term and premature newborns. Our results (see Table 1) are an unbiased confirmation of such situation.

The data of analysis presented here have become an evident background for changes in organization of health care providing for newborn babies.

To increase the availability and quality of health care aid for mothers and babies, it was necessary to perfect a lot of medical institutions aiming to organize the three-level service of perinatal aid providing, such a service being known to function in many developed countries.

From the end of the XX century, the regionalization of perinatal medical aid became a standard of perinatal health care. It includes guarantees of its availability and assuring of its succession and step-by-step character based on the clear distribution of perinatal aid institutions according to levels of health care services, implementation of unified standards, recommendations, and order of patient hospitalization and transfer to institutions of different levels [10,15]. It became an organizational model on the way of medical aid optimization for mothers and children; it assures the step-by-step providing of medical services in institutions of three levels, taking into consideration regional peculiarities; such a system foresees the timeliness, availability, adequacy, efficacy, and safety of the aid accompanied by rational cost expenditure for aims of the health protection; such a system promotes also the decrease of maternal and perinatal mortality as well as of morbidity and disability rates.

Here we discuss the perinatal aid realization as a component of the health care system reformation as a whole.

The realization of perinatal aid regionalization has been carried out under some legal conditions. It was, first of all, the realization of the Decree of the President of Ukraine
(12.03.2010) concerning the implementation of economical reforms program during 2010-2014; the program foresaw the modernization of the tertiary (highly specialized) health care system including also perinatal aid and organization of perinatal centers (PCs) of tertiary perinatal aid [16]. Realization of the document mentioned was carried out through the fulfillment of the National Project "New Life Brings New Quality of Maternity and Childhood Protection".

A series of decrees of the Ministry of Health of Ukraine has been prepared and published, especially the decree № 514 "On the Confirmation of the Approximate Regulations for a Perinatal Center with In-Patient Department and of the Approximate Regulations for a Perinatal Center Belonging to a Health Care Institution" on the 15.08.2011, the decree № 726 “On the Perfection of Organization Concerning the Aid Providing to Mothers and Newborn Babies in Perinatal Centers" published on the 31.10.2011, and the decree № 1881 “On the Confirmation of the Secondary (Specialized) Health Care Volume Providing which is to Be Guaranteed by Multi-Profile Intensive Therapy Hospitals of the First and Second Levels as well as Changes to the Order of Perinatal Aid Regionalization" published on the 19.10.2018 [17, 18, 19].

These measures having been taken, new approaches for practical realization aiming the formation of three-level perinatal aid system were found together with monitoring fulfillment to evaluate its completeness and efficacy.

\section{CONCLUSIONS}

Perinatal aid realization in Ukraine is now carried out according to international strategies permitting to provide effective perinatal aid to patients at each level of its provision depending on patient's need. A modern and globally accepted system of three-level perinatal aid has been organized in the majority of regions where tertiary level perinatal centers function.

The system accepted has determined the directions of practical realization for three-level perinatal aid system as well as monitoring methods and assessment of this system completeness and efficacy.

The perinatal aid regionalization has permitted to assure the highly technological aid in perinatal institutions of the third level for pregnant women with high perinatal risks; these patients include pregnant women with heart defects (63.2-69\%), circulatory system ones (48.5-50.5\%), diabetes mellitus (46.7\%-53.3\%); in institutions of second-third levels, there are $74.2-83.0 \%$ of patients with severe gestoses. 
According to functional possibilities of perinatal aid institutions of different levels, they assure $62 \%-64.5 \%$ of births with newborn body mass 500-999 $\mathrm{g}$ and 53.9\%$55.3 \%$ of ones with newborn body mass $1000-1499 \mathrm{~g}$ in perinatal clinics of the third level; it guarantees the better survival of newborn babies with body masses 500 $999 \mathrm{~g}$ and 1000-1499 $\mathrm{g}$ during their first $168 \mathrm{~h}$ of life: it reaches $60.1-65.1 \%$ and $89.4-90.4 \%$ of such newborns, respectively.

Efficacy of perinatal aid regionalization is confirmed by a positive tendency of perinatal mortality index; it has become significantly lower: in 2010 the perinatal mortality reached 10.54 cases per 1,000 newborn alive and dead babies, this index having dropped to 8.89 in 2019. The maternal mortality data have also decreased from 23.5 up to 14.9 cases per 100,000 of babies born alive

\section{REFERENCES}

1. Konventsiia pro prava dytyny vid 20 lystopada 1989 roku (Konventsiia ratyfikovana Postanovoiu Verkhovnoi Rady No 789-XII vid 27.02.91) [Convention on the Rights of the Children [the 20th of November 1989] (Ratified by the Verkhovna Rada Decree No 789-XII on the 27.02.91)]. (In Ukrainian).

2. Zahalna deklaratsiia prav liudyny vid 10 hrudnia 1948 roku [Universal Declaration of Human Rights [the 10th of December 1948]. Official Herald of Ukraine. 2008;93;3103:89. (In Ukrainian).

3. Program of Actions of the International Conference on the Problems of Population and Development, 1994/ International Conference on the Problems of Population and Development, Cairo, 5th-13th of September 1994]. New-York: ONU. 1995.

4. Platforma dii, pryiniata Chetvertoiu vsesvitnoiu konferentsiieiu pro stanovyshche zhinok vid 15 veresnia 1995 roku [Action Platform Accepted by the Fourth Global Conference about the State of Women published on the 15th of September 1995. (In Ukrainian).

5. Zdorov'e-21: Osnovy politiki dostizheniya zdorov'ya dlya vsekh v Evropejskom regione VOZ: vvedenie (Evropejskaya seriya po dostizheniyu zdorov'ya dlya vsekh, 6). ISBN 9289043490 (Klassifikaciya NLM: WA 540 GA1) ISSN 1012-7380. [Health-21: Fundamentals of Health Policy for all in the WHO European Region: Introduction (European Series for Health of all). (In Russian).

6. UNO Millennium Declaration-Millennium Development Goals for 20002015. https://www.un.org/millenniumgoals/.

7. Tsili staloho rozvytku 2016-2030 [Goals of Permanent Development. 2016-2030]. http://www.un.org.ua/ua/tsili-rozvytku-tysiacholittia/ tsili-staloho-rozvytku. (In Ukrainian).

8. The Global Strategy for Women's, Children's and Adolescents' Health (2016-2030)_Every Woman Every Child. http://www.who.int/lifecourse/partners/global-strategy/en.

9. Rynhach N.0. Otsinka dosiahnennia Tsili Rozvytku Tysiacholittia shchodo znyzhennia dytiachoi smertnosti [Assessment of Achievements. Goals of Millennium Development Concerning Children Mortality Decrease]. 2013;2(20):25-36. doi:10.15407/dse2013.02.028 N. (In Ukrainian).

10. Moiseienko R.O., Vaisberh Yu.R., Holianovskyi V.O. et al. Natsionalni pidkhody do vprovadzhennia systemy rehionalizatsii perynatalnoi dopomohy v Ukraini za redaktsiieiu Moiseienko R. 0. [National Approaches to the Implementation of the Perinatal Aid Regionalization in Ukraine]. Kyiv: Ministry of Health of Ukraine; 2012, 136 pp. (In Ukrainian).
11. Shchorichna dopovid "Pro stan zdorovia naselennia, sanitarnoepidemichnu sytuatsiiu ta rezultaty diialnosti systemy okhorony zdorovia Ukrainy. 2017 rik." [Annual Report "On the Health State of Population, Sanitary/Epidemic Situation, and Results of Health Care System Functioning in Ukraine. 2017"]. Ministry of Health of Ukraine. State Enterprise "Ukrainian Institute of Strategic Investigations of the Ministry of Health of Ukraine". Kyiv: Medical Exposition Center "Medinform". 2018. (In Ukrainian).

12. Znamenska T. K., Vorobiova 0. V., Dudina 0.0 et al. Kharakterystyka diialnosti zakladiv perynatalnoi dopomohy v Ukraini: neonatolohichna sluzhba [Peculiarities of perinatal aid institutions activity in Ukraine]. Neonatologia, khirurgia ta perynatalna medytsyna. 2019;4(34):38-47. (In Ukrainian).

13. Hoida N.H., Dudina 0.0. Zdorovia zhinok reproduktyvnoho viku. Panorama okhorony zdorovia naselennia Ukrainy [Health of Reproductive Age Women. Panorama of Population Health Care in Ukraine]. Kyiv, 2003, p. 62-64. (In Ukrainian).

14. Znamenska T.K., Antypkin Yu.H., Ariaiev M.L. et al. Neonatolohiia u trokh tomakh za redaktsiieiu dokt. med. nauk, prof. T. K. Znamenskoi [Neonatology. Manual in 3 tomes edited by Znamenska T.K. (Professor, Doctor of Medical Sciences)]. Lviv: publisher Marchenko T.V. 2020;1:408. (In Ukrainian).

15. Antypkin Yu. H., Znamenska T.K., Marushko, R.V. et al. Stan medychnoi dopomohy novonarodzhenym v Ukraini [State of the neonatal health care in Ukraine]. Neonatologia, khirurgia ta perynatalna medytsyna. 2020;4(38):5-24. (In Ukrainian).

16. Ukaz Prezydenta Ukrainy vid 12 bereznia 2012 roku № 187/2012 "Natsionalnyi plan dii na 2012 rik shchodo vprovadzhennia Prohramy ekonomichnykh reform na 2010-2014 roky "Zamozhne suspilstvo, konkurentospromozhna ekonomika, efektyvna derzhava" [Decree of the President of Ukraine published on the 12th of March 2012 № 187/2012 "National Plan of Actions in 2012 Concerning the Implementation of the Program of Economical Reforms in 2010-2014“Prosperous Society, Competitive Economics, Effective State"]. (In Ukrainian).

17. Nakaz Ministerstva okhorony zdorovia Ukrainy vid 15.08.2011 № 514 "Pro zatverdzhennia Prymirnoho statutu Perynatalnoho tsentru zi statsionarom ta Prymirnoho polozhennia pro Perynatalnyi tsentr u skladi zakladiv okhorony zdorovia" [Decree of the Ministry of Health of Ukraine published on the 15.08.2011 № 514 "On the Confirmation of the Approximate Regulations for a Perinatal Center with In-Patient Department and of the Approximate Regulations for a Perinatal Center Belonging to a Health Care Institution"]. (In Ukrainian).

18. Nakaz Ministerstva okhorony zdorovia Ukrainy vid 31.10.2011 № 726 "Pro udoskonalennia orhanizatsii nadannia dopomohy materiam ta novonarodzhenym v perynatalnykh tsentrakh" [Decree of the Ministry of

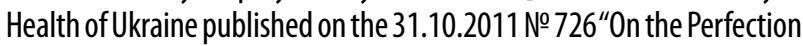
of Organization Concerning the Aid Providing to Mothers and Newborn Babies in Perinatal Centers"]. (In Ukrainian).

19. Nakaz Ministerstva okhorony zdorovia Ukrainy vid 19.10.2018 № 1881“Pro zatverdzhennia Obiemu nadannia vtorynnoi (spetsializovanoi) medychnoi dopomohy, shcho povynen zabezpechuvatysia bahatoprofilnymy likarniamy intensyvnoho likuvannia pershoho ta druhoho rivnia, ta Zmin do Poriadku rehionalizatsii perynatalnoi dopomohy". [Decree of the Ministry of Health of Ukraine published on the 19.10.2018 № 1881 “On the Confirmation of the Secondary (Specialized) Health Care Volume Providing which is to Be Guaranteed by Multi-Profile Intensive Therapy Hospitals of the First and Second Levels as well as Changes do the Order of Perinatal Aid Regionalization"]. (In Ukrainian). 
The article was performed in framework of research "The clinical and katamnestic investigation of the development of children development with the damage of a nervous system in a perinatal period" (2018-2022, № state registration 0119U101040).

\section{ORCID and contributionship:}

Raisa O. Moiseienko: 0000-0001-6727-8742 ${ }^{A, D, F}$

Nina G. Gojda: 0000-0001-6625-0078 C,E,F

Olena O. Dudina: 0000-0001-9828-976X ${ }^{B, C}$

Natalia M. Bodnaruk: 0000-0003-1033-9238 A,B,D

\section{Conflict of interest:}

The Authors declare no conflict of interest.

\section{CORRESPONDING AUTHOR}

Raisa 0. Moiseienko

P.L.Shupyk National Medical Academy of Post-Graduate Education

9 Dorogozhytska St., 04112 Kyiv, Ukraine

tel: 205-49-48

e-mail: v-moiseenko@ukr.net

Received: 28.11 .2020

Accepted: 12.03 .2021

A - Work concept and design, B - Data collection and analysis, C - Responsibility for statistical analysis,

D-Writing the article, E-Critical review, F- Final approval of the article 